\title{
Pengembangan Multimedia Interaktif Untuk Pembelajaran Tipografi
}

\author{
Abd. Aziz Ahmad \\ Dosen Seni Rupa Fakultas Seni dan Desain UNM Makassar
}

\begin{abstract}
Abstrak: Tujuan penelitian ini adalah mengembangkan multimedia interaktif untuk pembelajaran Tipografi dalam mata kuliah Disain Komunikasi Visual dan untuk menemukan keefektifan multimedia yang telah dikembangkan. Penelitian ini dilakukan terhadap mahasiswa Semester II Tahun Akademik 2005/2006 dan 2006/2007 pada Program Studi Pendidikan Seni Rupa Jurusan Seni Rupa Fakultas Seni dan Desain Universitas Negeri Makassar, dengan responden sebanyak 68 orang. Hasil penilaian menunjukkan bahwa multimedia interaktif dapat digunakan dalam pembelajaran di kelas. Berdasarkan analisis uji-t, menunjukkan bahwa program multimedia efektif digunakan sebagai media pembelajaran.
\end{abstract}

Kata kunci: multimedia interaktif, seni lukis, tipografi, kaligrafi, dan efektif.

\begin{abstract}
The aim of this research is to develop interactive multimedia for Typography learning in the Visual Communication Design subject and to find out the effectiveness of multimedia that has been developed. The study was conducted at The Department of Art Education, Faculty of Languages and Arts, State University of Makassar in the second semester of 2005/2006 and 2006/2007 Academic Year. The result of this research: 1 ) this multimedia is applicable for classroom instruction; and based on the $t$-test analysis of the student achievement shows that the multimedia program is effective for students learning.
\end{abstract}

Key words: multimedia, painting, tipography, calligraphy, and effective.

\section{Pendahuluan}

Dunia pendidikan sebagai ajang mencerdaskan kehidupan bangsa dan meningkatkan mutu sumber daya manusia, turut pula memanfaatkan kecanggihan program multimedia tersebut, baik itu perangkat keras maupun perangkat lunak. Sebagai salah satu contoh adalah pengembangan pembelajaran interaktif melalui program multimedia. Paket program multimedia adalah suatu produksi yang menggunakan lebih dari satu medium untuk tujuan komunikasi yang diintegrasikan lewat komputer.

Dalam kaitan peningkatan mutu proses belajar, seorang tenaga pengjar dituntut melakukan pengembangan dan perbaikan terhadap bidang studi atau mata kuliah yang dibinanya. Hal ini berarti seorang dosen dituntut mengadakan penyesuaian, pembaharuan bahkan bila perlu reformasi dalam proses belajar untuk mengikuti perkembangan zaman.

Salah satu mata kuliah keahlian (MKK) dalam Program Studi Pendidikan Seni Rupa dan Desain Komunikasi Visual Fakultas Seni dan Desain (FSD) Universitas Negeri Makassar adalah pembelajaran Tipografi. Mata kuliah ini bertujuan agar mahasiswa memiliki keterampilan merancang huruf untuk komunikasi visual ditinjau dari aspek typefaces, kepekaan dalam menterjemahkan bahasa verbal menjadi konfigurasi visual dan aplikasi berbagai disain grafis. Sebelum bergabung dalam mata kuliah Disain Komukasi Visual, Tipografi berdiri sendiri sebagai salah satu mata kuliah bernama Disain Aksara. Dengan mengemas dalam bentuk program multimedia interaktif, diharapkan dapat meningkatkan motivasi dan minat mahasiswa dalam mempelajari tipografi.

\section{Kajian Literatur}

Ada beberapa istilah yang digunakan dalam penelitian ini yang dipandang perlu untuk memberikan keterangan lebih lanjut atau deskripsi teoretis atas istilah tersebut. Belajar diartikan sebagai proses perubahan perilaku, misalnya orang yang tidak dapat mengenal huruf menjadi mampu mengenal huruf sekaligus dapat membacanya, orang yang tidak terampil menulis menjadi terampil menulis, tidak bisa melukis menjadi bisa melukis, dan berbagai perubahan perilaku lainnya.

Menurut Sadiman (1996: 1), belajar adalah suatu proses yang kompleks yang terjadi pada semua orang dan berlangsung seumur hidup, sejak dia masih bayi hingga ke liang lahat nanti. 
Salah satu pertanda bahwa seseorang telah belajar sesuatu adalah adanya perubahan tingkah laku dalam dirinya. Perubahan tingkah laku tersebut menyangkut baik perubahan yang bersifat pengetahuan (kognitif) dan keterampilan (psikomotor) maupun yang menyangkut nilai dan sikap (afektif).

\section{Hakikat Pembelajaran Mutimedia Interaktif}

Penggunaan multimedia dalam proses belajar mengajar ini dimaksudkan agar mahasiswa termotivasi untuk belajar dan dapat menimbulkan daya tarik dalam proses belajarnya sehingga diperoleh hasil belajar maksimal. Kesemuanya itu dilakukan agar hasil (outcome) pembelajaran yang disampaikan dapat memenuhi kriteria efektif, efisiensi, dan daya tarik. Sesuai dengan pernyataan Reigeluth (1983: 20) bahwa, secara umum hasil pembelajaran dikategorikan ke dalam tiga hal yaitu: 1) Efektif, diukur dari prestasi belajar mahasiswa; 2) Efisiensi, diukur dengan keefektifan dibagi oleh waktu belajar mahasiswa dan/biaya pengembangan pembelajaran; dan 3) Memiliki daya tarik (appeal), diukur atas adanya kecenderungan mahasiswa untuk tetap betah melanjutkan proses belajarnya.

Dari berbagai aliran dalam filsafat pengetahuan; di antaranya; Objektivisme, Konstruktivisme, Behaviorisme, Idealisme, Maturasionisme dan sebagainya, ternyata program multimedia dalam pembelajaran dirancang dari sudut pandang aliran konstruktivisme. Sebagaimana yang dinyatakan oleh Phillips (1997: 21);

Interactive Multimedia (IMM) software designed from a constructivist viewpoint can take advantage of all aspects of IMM. Material is designed so the student can build their own knowledge instead of the instructor dictating it.

Pendekatan konstruktivisme menekankan kepada mahasiswa agar belajar dan melakukan sesuatu (learning and doing), dilakukan dengan berbagai cara, di antaranya menggunakan program multimedia dalam hal membantu mahasiswa mencapai tingkatan tertinggi dalam berfikir. Menurut Von Glaserfeld dalam Bettencourt (1989) dan Matthews (1994) dikutip Pannen dkk (2001: 3) bahwa, konstruktivisme merupakan salah satu aliran filsafat pengetahuan yang menekankan bahwa pengetahuan kita merupakan hasil kon- struksi (bentukan) kita sendiri. Tugas seorang dosen adalah menyiapkan materi pembelajaran, memberi penjelasan, membantu dan menfasilitasi dan selanjutnya membiarkan mereka (mahasiswa) mensintesis sebisa mungkin pengetahuan yang dimilikinya.

Selanjutnya pengertian tentang program multimedia, adalah media pembelajaran yang berbasis komputer, media ini menggabungkan dan mensinergikan semua media yang terdiri dari teks, grafis, foto, video, animasi, musik, narasi, dan interaktivitas yang diprogramkan berdasarkan teori pembelajaran (http//www.pustekkom.go.id/ multimedia.htm).

\section{Format Multimedia Pembelajaran Interaktif}

Menurut Schwier and Misanchuk (1993: 20, terdapat beberapa format pembelajaran multimedia, di antaranya: latihan (drill and practice), bimbingan (tutorial), permainan atau simulasi (games/-simulation). Sedangkan Alessi \& Trollip (1991: 92-183) merinci format pembelajaran tersebut sebagai berikut.

\section{Drill}

Selama proses drill komputer memberikan praktek dan umpan balik terhadap topik-topik yang diajarkan di dalam pertemuan lain, bahkan mungkin saja dengan bantuan media lain.

\section{Tutorial}

Format tutorial, komputer mengajarkan informasi baru, dengan menyajikan konsep-konsep. Pemahaman mahasiswa tentang apa yang diajarkan kemudian diukur. Kadang-kadang diberikan pembelajaran lain dalam bentuk pembelajaran pengayaan atau remedial, tergantung pada jawaban atau respon yang telah diberikan oleh mahasiswa.

Dalam struktur ini kegiatan dimulai dari pendahuluan (introductory section) yang berisi informasi tentang tujuan yang diharapkan dari mahasiswa. Kemudian penyajian materi (present information) disertai dengan beberapa pertanyaan. Pertanyaan dan respon (question and response) yang diberikan oleh mahasiswa, dinilai (judge response) dan sekaligus sebagai umpan balik (feedback), yang dapat digunakan untuk menampilkan kinerja di masa mendatang. Bila hasil 
yang dicapai belum mencapai standar, maka diadakan remedial (remediation), jika baik maka dilanjutkan pada materi berikutnya, begitu seterusnya sampai materi yang akan disampaikan selesai. Jika materi telah selesai, langkah berikutnya adalah menutup (closing), yang berisi informasi rangkuman dari keseluruhan materi yang baru disampaikan.

\section{Games}

Format games biasanya berkaitan dengan tujuan khusus yang melibatkan penilaian suatu kompetisi. Biasanya dalam suatu game tidak disertakan petunjuk, karena tujuan utamanya adalah sekedar hiburan atau mempertunjukan pengalaman yang biasa dialami sendiri. Kemampuan komputer untuk memanipulasi angka, memberikan gambaran yang menarik pada layar monitor. Seperti halnya stimulasi, games pembelajaran yang baik, namun sukar dirancang dan perancang harus yakin bahwa dalam upaya memberikan suasana permainan, integritas tujuan pembelajaran tidak hilang.

\section{Simulasi}

Dalam format simulasi, penayangan di komputer dapat mensimulasikan atau memberi model konsep-konsep yang kompleks atau kejadiankejadian tertentu. Komputer menerima masukan dari mahasiswa dan memberikan respon atas dasar masukan yang diberikan, sehingga mahasiswa dapat mengalami hasil pengambilan keputusannya tanpa adanya konsekuensi yang membahayakan atau menghabiskan biaya yang mahal.

Selanjutnya, format yang menjadi pilihan dalam pengembangan pembelajaran Tipografi ini adalah format tutorial, dengan pertimbangan utama adalah kesesuaiannya dengan tujuan pembelajaran, yaitu mengajarkan informasi baru, memotivasi mahasiswa dan merupakan pembelajaran pendahuluan.

\section{Hakikat Pembelajaran Tipografi}

Dalam perancangan suatu pesan dalam karya seni lukis kaligrafi, tidak terlepas dari pengaturan bentuk serta ukuran besar kecilnya huruf, hal itulah yang diatur dalam tipografi. Menurut Kusrianto (2004: 93) bahwa, tipografi adalah salah satu unsur yang penting dalam menyusun sebuah lay-out. Sebagai unsur grafis ia memiliki kekuatan yang tidak kalah hebatnya dengan unsur ilustrasi maupun photo.

Ditambahkan oleh Folsom (1990: 124) bahwa tipografi adalah seni memilih huruf yang tepat dalam suatu rancangan dan menatanya dengan cara tertentu sehingga terkomunikasikan dengan efisien serta menyenangkan dipandang mata. "The art of choosing appropriate type for a project and arranging it in a way that communicates efficiently and is pleasing to the eye".

Tipografi merupakan suatu ilmu dalam memilih dan menata huruf dengan pengaturan penyebarannya pada ruang-ruang yang tersedia, untuk menciptakan kesan tertentu, sehingga dapat menolong pembaca untuk mendapatkan kenyamanan membaca semaksimal mungkin (http:// id. wikipedia.org/-wiki/Tipografi).

Sedangkan deskripsi pembelajaran Tipografi adalah mengkaji tentang huruf dan aplikasinya pada disain grafis. Kajian meliputi peranan dan perkembangan huruf. Keterampilan dasar membuat dan merancang huruf, sebagai simbolisasi, asosiasi dan interpretasi huruf serta penerapannya pada media visual dan perancangan komunikasi visual.

Pada perkembangan selanjutnya, keterampilan menata huruf ini diaplikasikan pula dalam bidang Seni Lukis, khususnya dalam lukisan kaligrafi.

Istilah kaligrafi berasal dari bahasa Inggris "Calligraphy" yang mereka adopsi dari bahasa Latin "kalios" yang berarti indah, dan "graph" berarti tulisan.

Jadi, dapat disimpulkan bahwa pengetahuan dasar tentang tipografi sangat penting artinya dalam perancangan suatu karya kaligrafi. Pengetahuan dan keterampilan tentang tipografi dan kaligrafi saling melengkapi dan saling mendukung satu sama lainnya dalam upaya menghasilkan sebuah karya seni.

\section{Aksara Latin}

Aksara Latin biasa pula disebut aksara Romawi (Roman Alphabet), istilah lain dari abjad Latin. Tulisan ini berasal dan berkembang di daratan Roma ibukota Italia sekitar 700 tahun sebelum Masehi, bentuk tulisan ini adalah hasil adopsi dari 
abjad fonesis dari Yunani, cara penulisannya dari kanan ke kiri. Pada awalnya, ada 13 huruf yang diadopsi dari bahasa Yunani tanpa dimodifikasi yaitu: ABEHI KMN OXTYZ, kemudian penyesuaian bahasa (Latin) 7 huruf (C D G L P R S), selanjutnya ditambah lagi 3 huruf (F Q V). Pada abad pertengahan, aksara Latin mendapat tambahan lagi tiga huruf yaitu $\mathrm{J}, \mathrm{U}$, dan $\mathrm{W}$ representasi dari huruf I dan U. Tulisan Latin ini digunakan oleh banyak orang di dunia, sebagaimana dinyatakan oleh Nakanishi (1998: 14), "Latin script, which is the most widely used in the world today, was originally the writing of the ancient Roman Empire".

\section{Aksara Arab}

Abjad Aksara Arab atau Huruf Hijaiyah, menurut Sirojuddin AR (2000:25), jumlah hurufnya yang digunakan dalam berbagai bahasa di dunia berkisar antara 24 hingga 36. Terhitung dalam

\section{Metode Penelitian}

Secara metodologis penelitian ini dilaksanakan melalui prosedur Penelitian dan Pengembangan (Reseach and Development), dengan uji coba lapangan. Penelitian pengembangan dalam pendidikan adalah suatu proses untuk mengembangkan dan menvalidasi produk pendidikan termasuk obyek material dan prosedur serta proses seperti; metode pengajaran dan pengeIolaan pembelajaran. Sesuai dengan pengertian tersebut, maka penelitian ini berupaya menghasilkan suatu produk program multimedia yang efektif.

\section{Langkah-langkah Riset Pengembangan}

Dalam penelitian ini digunakan sembilan langkah. Kesembilan langkah ini dimodifikasi dari metode penelitian dan pengembangan yang diformulasi oleh Borg and Gall (1973: 414-415), sebagai berikut:

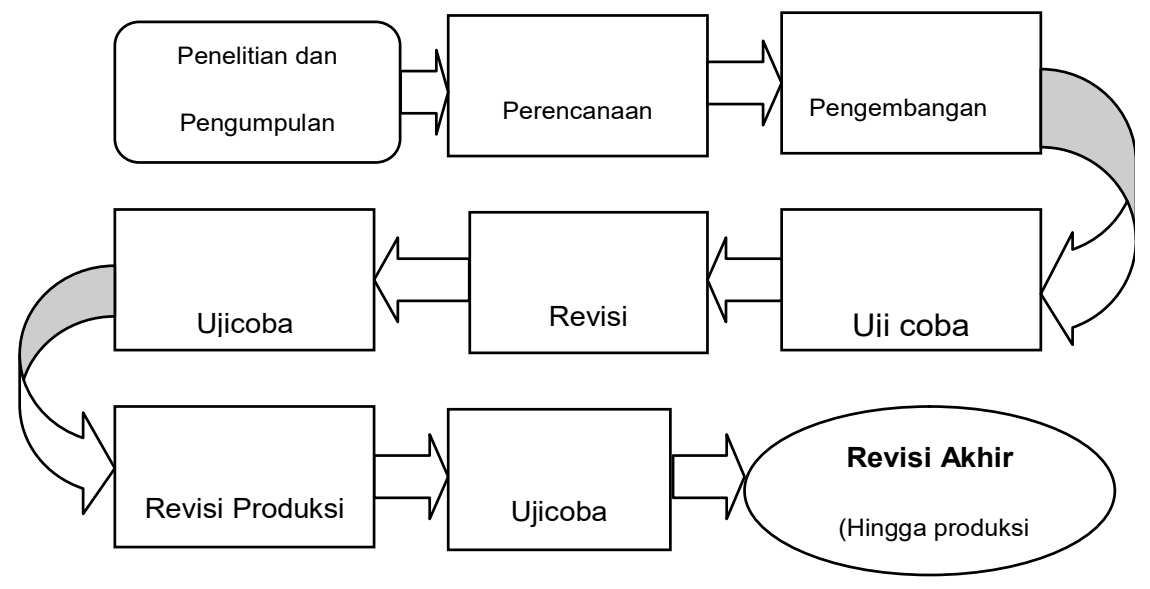

Bagan 1. Tahapan Pengembangan Program Multimedia

Alquran terdiri dari 28 huruf menurut ucapan, sedangkan yang populer di Indonesia berjumlah 30 huruf.

\section{Aksara Lontara}

Aksara Lontara adalah salah satu aksara yang diajarkan dalam pembelajaran tipografi. Penamaan aksara Lontara atau aksara BugisMakassar diambil dari nama dua suku bangsa yang mendiami Pulau Sulawesi bagian selatan, yaitu suku Bugis dan suku Makassar. Selain kedua suku bangsa tersebut di Sulawesi Selatan terdapat pula suku Toraja dan Mandar.
Pertama, penelitian dan pengumpulan informasi; langkah pertama dalam pengembangan program multimedia adalah mengadakan penelitian terhadap materi pembelajaran yang dikembangkan misalnya dengan membaca literatur termasuk mempelajari hasil produk program multimedia. Pada tahap ini diadakan observasi dan analisis kebutuhan dengan mempertimbangkan kelayakan produksi. Kedua, perancangan prototipe pembelajaran;

Langkah berikutnya adalah mendesain pembelajaran dengan mengacu pada teori belajar, misalnya dalam hal penyusunan materi pembelajaran; dari materi yang sederhana ke yang 
rumit atau dari bahasan yang mudah ke yang sulit. Termasuk dalam hal ini kesesuaian antara contohcontoh yang menyertai suatu pokok bahasan. Kemudian dilengkapi dengan cara penilaian hasil belajar. Ketiga, pengembangan produksi awal; pada tahapan ini dilakukan produksi program, dengan langkah-langkah sebagai berikut; penyusunan naskah, membuatan desain tampilan atau background layar, pembuatan animasi, pengetikan, dan penyediaan stock gambar, foto, video dan narasi. Selanjutnya diadakan pemprograman dan proses editing. Dicermati pula audionya serta kelancaran fungsi tombol-tombol yang digunakan, dan tak kalah pentingnya adalah memperhatikan kebenaran isi pembelajaran. Keempat, uji coba terbatas (Preliminary field testing); uji coba terbatas dilakukan terhadap pengembang dan programmer. Kelima, revisi produksi awal; berdasarkan masukan hasil uji coba tahap pertama telah diadakan revisi. Keenam, uji coba kelompok kecil. Kegiatan uji coba ini melibatkan subyek 21 orang mahasiswa Program Studi Pendidikan Seni Rupa FSD UNM Makassar, tahun ajaran 2005/2006. Ketujuh, revisi produksi tahap II; setelah data melalui angket telah dikumpulkan, kemudian dianalisis untuk menentukan pada bagian mana yang memerlukan perbaikan dan revisi program. Kedelapan, uji coba lapangan; kegiatan uji coba lapangan ini melibatkan subjek 33 orang mahasiswa FSD UNM Makassar Tahun Ajaran 2006/2007. Kesembilan, revisi akhir; diadakan revisi akhir atau revisi ketiga, dilakukan berdasarkan hasil angket, wawancara, saran, dan komentar yang diberikan oleh responden. Hingga produksi dianggap layak untuk digunakan.

\section{Sasaran klien dan Sampel Penelitian}

Sedangkan yang menjadi sasaran klien penelitian ini adalah mahasiswa Program Studi Pendidikan Seni Rupa Jurusan Seni Rupa Fakultas Seni dan Desain Universitas Negeri Makassar. Sampel melibatkan 54 mahasiswa.

\section{Tempat dan Waktu}

Penelitian ini dilakukan di kampus Fakultas Seni dan Desain Universitas Negeri Makassar, Jalan Gaeng Tata Raya Makassar. Sedangkan waktunya mulai April 2006 sampai dengan Juli 2007.

\section{Teknik Pengumpulan Data}

Data dikumpulkan melalui sejumlah angket yang telah disebarkan kepada mahasiswa yaitu kepada mahasisa Jurusan Pendidikan Seni Rupa FSD UNM Makassar. Di samping penyebaran angket (koesioner), dilakukan pula wawancara dengan ahli media dan ahli Content (isi) yang dianggap dapat memberikan kontribusi terhadap permasalahan yang diteliti, terutama kepada dosen pengampu mata kuliah tipografi.

\section{Teknik Analisis Data}

Analisis data dalam penelitian pengembangan ini adalah bersifat deskriptif. Data yang diperoleh dideskripsikan dengan menggunakan rumus prosentase.

Prosentase Jawaban: $\frac{\mathrm{F}}{\mathrm{N}} \times 100 \%$

Keterangan:

$\mathrm{F}=$ frekuensi subyek yang memilih alternatif

$\mathrm{N}=$ Jumlah keseluruhan subyek.

\section{Hasil Penelitian dan Pembahasan}

Hasil penelitian ini meliputi: 1) pengembangan program multimedia pembelajaran Tipografi; dan 2) keefektifan program.

\section{Pra Produksi: Penentuan Kebutuhan Belajar Mahasiswa}

Kebutuhan belajar yang pokok bagi mahasiswa Program Studi Pendidikan Seni Rupa di Perguruan Tinggi adalah kebutuhan untuk memperoleh pengetahuan, sikap serta keterampilan dalam bidang kesenirupaan. Salah satu aspek dari bidang kesenirupaan yang dipandang sebagai kebutuhan belajar mahasiswa adalah kebutuhan untuk memperoleh pengetahuan serta keterampilan dalam penataan dan perancangan berbagai huruf.

\section{Tahapan produksi:Langkah-Langkah Produksi sebagai berikut.}

Pertama, penyusunan naskah. Naskah program pembelajaran tipografi disusun berdasarkan materi pembelajaran yang diambil dari kurikulum. Kedua, desain tampilan. Setelah naskah (storyboard) selesai ditulis, langsung pada kegiatan produksi, yaitu dengan membuat desain tampilan 
utamanya desain untuk latar belakang (background) layar. Mengingat tampilan pada layar hampir mendominasi penampilan keseluruhan program, maka hal ini sangat penting dan menjadi prioritas utama. Ketiga, pembuatan animasi. Dengan animasi diharapkan dapat menimbulkan daya tarik dalam mempelajari materi program yang ditayangkan. Keempat, pengetikan teks. Pengetikan teks atau naskah menggunakan program Microsoft Word, agar memudahkan bagi programmer menggabungkan dalam program editing multimedia (Macromedia Authorware). Naskah dan storyboard menjadi panduan bagi programmer. Kelima, penyediaan stock foto, gambar, video dan narasi. Foto dan gambar yang diambil dari buku-buku referensi pembelajaran Tipografi dijadikan format digital, setelah terlebih melalui proses pengeditan.

\section{Hasil Uji Coba Perorangan}

Uji coba perorangan, diberikan kepada masingmasing dosen dan mahasiswa, adalah sebagai berikut:

\section{Tanggapan Dosen}

Materi: 1) Rumusan kompetensi pembelajaran tipografi yang disebutkan di awal masih sangat sempit. Saran saya rumusan tersebut perlu dikembangkan, misalnya kompetensi menyangkut manfaat pengetahuan tipografi, berbagai aplikasi pengetahuan, ruang lingkup atau bidang garapan ketipografian; 2) Secara otomatis pengembangan kompetensi akan diikuti pengembangan materi; 3) Materi yang disajikan masih perlu dilengkapi untuk mencapai kompetensi yang telah ditetapkan, terutama yang menyangkut perkembangan perangkat media, pengertian dan peristilahan dalam tipografi dan kaligrafi; dan 4) Gambar ilustrasi atau animasi yang ditampilkan belum sepenuhnya mempertegas pemahaman tentang materi yang dijelaskan.

\section{Tanggapan Mahasiswa}

Menyangkut petunjuk penggunaan program, keterbacaan teks/tulisan, tampilan gambar, animasi, komposisi warna, kejelasan suara dan musik. Pengamat memberi skor B (baik).

Kejelasan tujuan pembelajaran, petunjuk belajar, kemudahan memahami kalimat pada teks, kecukupan latihan, dan umpan balik. Pengamat memberi nilai skor C (cukup). Sedangkan Ketepatan urutan penyajian dan bantuan belajar dengan program, Pengamat memberi skor B (baik).

Menurut responden bagian yang menarik adalah: materi programnya. Program multimedia dapat membantu proses belajar mengajar, misalnya dalam hal kemudahan dalam menerima materi. Melalui program multimedia lebih menarik sehingga mahasiswa tidak merasa bosan dan lebih mengerti tentang materi yang disajikan. Pengamat berkesimpulan bahwa program multimedia pembelajaran tipografi ini secara umum menarik dan menumbuhkan motivasi belajar.

\section{Hasil Uji Coba Kelompok Kecil}

Berikut ini disajikan data analisis deskriptif prosentase hasil uji coba Kelompok Kecil.

Masukan berupa saran, kritik, dan komentar dari mahasiswa uji coba kelompok kecil ini dijadikan dasar untuk merevisi program.

\section{Hasil Uji Coba Lapangan}

Produk program multimedia yang telah beberapa kali mengalami perbaikan selanjutnya diujicobakan kepada mahasiswa dalam jumlah yang lebih besar. Maksud dari uji coba ini adalah untuk mengetahui tingkat keefektifan dan kualitas produk tersebut. Data yang diperoleh dalam uji coba lapangan ini terdiri atas: a) hasil tanggapan dosen mata kuliah; b) hasil penilaian mahasiswa terhadap program multimedia; dan c) hasil tes awal dan tes akhir pembelajaran tipografi, untuk melihat sejauh mana keefektifan program yang telah dikembangkan.

\section{Tanggapan Dosen Mata Kuliah}

Data dari dosen mata kuliah Disain Komunikasi Visual dihimpun dengan menggunakan wawancara dan diskusi. Data yang diperoleh adalah sebagai berikut: 1) Perlu perbaikan pada suara videonya, demikian pula pengaturan masalah akustik pada ruangan multimedia yang digunakan; 2) Program multimedia ini sangat efektif jika fasilitas ruang multimedia memadai, dan lebih efektif lagi jika dibagikan VCD program kepada masing-masing peserta mata kuliah agar mereka pelajari sendiri-sendiri atau dipelajari secara mandiri; 3) Kelemahannya: tidak semua maha- 
Tabel 1. Hasil Uji Coba Program Multimedia untuk Kelompok Kecil

\begin{tabular}{|c|c|c|c|c|}
\hline No. & Komponen Evaluasi & $\begin{array}{l}\text { Nomor butir } \\
\text { pertanyaan }\end{array}$ & $\begin{array}{c}\text { Jml } \\
\text { butir }\end{array}$ & $\begin{array}{c}\text { Rata-rata yg } \\
\text { menjawab } \\
\text { YA }\end{array}$ \\
\hline $\begin{array}{l}11 . \\
12 . \\
13 . \\
14 . \\
15 . \\
16 . \\
17 . \\
18 . \\
19 . \\
20 .\end{array}$ & $\begin{array}{l}\text { Kejelasan tujuan pmbelajaran } \\
\text { Kesesuaian tingkat pemahaman } \\
\text { mahasiswa } \\
\text { Keberurutan sajian materi } \\
\text { Ketersediaan contoh soal setiap pokok } \\
\text { bahasan } \\
\text { Kemudahan melakukan interaksi } \\
\text { dengan program } \\
\text { Kesesuaian pertanyaan dg materi } \\
\text { Kesesuaian umpan balik } \\
\text { Indikator keberhasilan pemakai terlihat } \\
\text { dari tes akhir (evaluasi) } \\
\text { Kesesuaian Model huruf (fonts) } \\
\text { dengan resolusi monitor } \\
\text { Ketepatan penggunaan bahasa dan } \\
\text { tampilan layar } \\
\text { Kemudahan pengoperasian } \\
\text { Kemudahan pelaksanaan di kelas } \\
\text { Sistem manajemen di kelas } \\
\text { Dukungan musik pengiring } \\
\text { Ketajaman tayangan video } \\
\text { Kesesuaian desain grafis } \\
\text { Keharmonisan elemen visual } \\
\text { Kejelasan memahami narasi } \\
\text { Penampilan Animasi } \\
\text { Penutup Program }\end{array}$ & $\begin{array}{c}1,2 \\
3,5 \\
6 \\
7,8,9,10,11,12 \\
13,14,15 \\
16,17,18 \\
19,20,21 \\
22,23 \\
24,25,26,27 \\
28,29,30,31 \\
32,33,34,35 \\
36,37,38,39,40 \\
41,42,43 \\
44,45 \\
46,47,48,49,50,51 \\
52,53,54,55 \\
56,57,58, \\
59 \\
60\end{array}$ & $\begin{array}{l}4 \\
4 \\
4 \\
5 \\
3 \\
2 \\
6 \\
4 \\
3 \\
1 \\
1\end{array}$ & $\begin{array}{l}95,24 \% \\
61,90 \% \\
80,95 \% \\
\\
85,71 \% \\
63,49 \% \\
63,49 \% \\
65,07 \% \\
65,07 \% \\
\\
52,38 \% \\
\\
91,66 \% \\
71,43 \% \\
73,81 \% \\
79,99 \% \\
80,95 \% \\
95,24 \% \\
86,66 \% \\
85,71 \% \\
97,62 \% \\
86,90 \% \\
95,24 \%\end{array}$ \\
\hline & & Jumlah & 60 & \\
\hline
\end{tabular}

siswa memiliki fasilitas VCD/DVD player untuk memutarnya.

\section{Hasil Penilaian Mahasiswa}

Ada dua aspek yang menjadi penilaian dari mahasiswa dalam Uji coba Lapangan yaitu: 1) Kualitas Tampilan Program Multimedia dan 2) Penyajian Materi, yang dilengkapi dengan kesimpulan.

Uji coba program multimedia pembelajaran Tipografi ini dilakukan dengan tujuan untuk menentukan kelayakan tampilan, strategi interaksi pengguna, strategi interaksi program, dan kebenaran isi. Model penilaian tersebut bersumber dari buku Hannafin and Peck (1988: 305-310). Selanjutnya, hasil penilaian mahasiswa terhadap kualitas tampilan multimedia dan penyajian materi dalam bentuk persentase.

Terlihat hasil respon mahasiswa terhadap kualitas tampilan program multimedia berada pada tingkatan B (Baik). Yaitu skor rata-rata 47,31\%.

Tabel 2. Kualitas Tampilan Multimedia

\begin{tabular}{|l|l|c|c|c|c|c|c|}
\hline \multirow{2}{*}{ No. } & \multirow{5}{|c|}{ Persentase } \\
& & \multicolumn{5}{|c|}{} \\
\cline { 3 - 7 } & & $S B$ & $B$ & $C$ & $K$ & $S K$ & $J M L$ \\
\hline 01. & $\begin{array}{l}\text { Kejelasan petunjuk } \\
\text { penggunaan program }\end{array}$ & $30,30 \%$ & $54,54 \%$ & $3,03 \%$ & $12,12 \%$ & $0 \%$ & $99,99 \%$ \\
\hline 02. & $\begin{array}{l}\text { Keterbacaan } \\
\text { teks/tulisan }\end{array}$ & $39,40 \%$ & $57,57 \%$ & $0 \%$ & $3,03 \%$ & $0 \%$ & $100 \%$ \\
\hline 03. & $\begin{array}{l}\text { Kualitas tampilan } \\
\text { gambar }\end{array}$ & $24,24 \%$ & $57,57 \%$ & $15,15 \%$ & $3,03 \%$ & $0 \%$ & $99,99 \%$ \\
\hline 04. & Sajian animasi & $21,88 \%$ & $43,75 \%$ & $18,75 \%$ & $12,5 \%$ & $3,12 \%$ & $100 \%$ \\
\hline 05. & Komposisi warna & $18,18 \%$ & $54,54 \%$ & $18,18 \%$ & $9,09 \%$ & $0 \%$ & $99,99 \%$ \\
\hline 06. & $\begin{array}{l}\text { Kejelasan } \\
\text { suara/narasi }\end{array}$ & $12,12 \%$ & $36,36 \%$ & $33,33 \%$ & $15,15 \%$ & $3,03 \%$ & $99,99 \%$ \\
\hline 07. & Daya dukung musik & $21,21 \%$ & $27,27 \%$ & $42,42 \%$ & $9,09 \%$ & $0 \%$ & $99,99 \%$ \\
\hline
\end{tabular}


Tabel 3. Penyajian Materi

\begin{tabular}{|c|c|c|c|c|c|c|c|}
\hline 08. & $\begin{array}{l}\text { Kejelasan tujuan } \\
\text { pelajaran }\end{array}$ & $33,33 \%$ & $45,45 \%$ & $15,15 \%$ & $3,03 \%$ & $3,03 \%$ & $99,99 \%$ \\
\hline 09. & $\begin{array}{l}\text { Kejelasan petunjuk } \\
\text { belajar }\end{array}$ & $27,27 \%$ & $45,45 \%$ & $21,21 \%$ & $3,03 \%$ & $3,03 \%$ & $99,99 \%$ \\
\hline 10. & $\begin{array}{l}\text { Kemudahan } \\
\text { memahami kalimat } \\
\text { pada teks/tulisan }\end{array}$ & $15,15 \%$ & $54,54 \%$ & $18,18 \%$ & $12,12 \%$ & $0 \%$ & $99,99 \%$ \\
\hline 11. & $\begin{array}{l}\text { Kemudahan } \\
\text { memahami materi } \\
\text { (isi) pelajaran }\end{array}$ & $12,12 \%$ & $57,57 \%$ & $15,15 \%$ & $15,15 \%$ & $0 \%$ & $99,99 \%$ \\
\hline 12. & $\begin{array}{l}\text { Ketepatan urutan } \\
\text { penyajian }\end{array}$ & $15,15 \%$ & $45,45 \%$ & $39,40 \%$ & $0 \%$ & $0 \%$ & $100 \%$ \\
\hline 13. & Kecukupan latihan & 6,25 & $53,13 \%$ & $34,37 \%$ & 6,25 & $0 \%$ & $100 \%$ \\
\hline 14. & $\begin{array}{l}\text { Kejelasan umpan } \\
\text { balik/respon }\end{array}$ & $18,18 \%$ & $30,30 \%$ & $33,33 \%$ & $15,15 \%$ & $3,03 \%$ & $99,99 \%$ \\
\hline 15. & $\begin{array}{l}\text { Bantuan belajar } \\
\text { dengan program }\end{array}$ & $30,30 \%$ & $39,39 \%$ & $24,24 \%$ & $3,03 \%$ & $3,03 \%$ & $99,99 \%$ \\
\hline
\end{tabular}

Keterangan: $S B=$ Sangat Bagus/Jelas $B=$ Bagus $C=$ Cukup $K=$ Kurang $S K=$ Sangat Kurang

Sedangkan respon mengenai penyajian materi, skor persentase yang menonjol pada tingkatan $B$ (Baik), yaitu skor $46,36 \%$. Di antara 33 subyek penelitian, terdapat 26 orang $(78,8 \%)$ yang menyimpulkan bahwa program multimedia pembelajaran tipografi ini cukup bagus, menarik dan menumbuhkan motivasi belajar (layak digunakan).

\section{Keefektifan Program Multimedia Pembelajaran Tipografi}

Untuk mengetahui keefektifan program, maka dilakukan tes awal dan tes akhir dan bertujuan untuk mengetahui sejauh mana produk yang diujicobakan dapat meningkatkan perolehan hasil belajar atau pencapaian kompetensi. Tes akhir diberikan kepada mahasiswa setelah mengikuti kegiatan pembelajaran adalah tes yang bersifat formatif yang berfungsi untuk memperoleh data dalam rangka pengembangan program multimedia pembelajaran tipografi.

Sebelum membahas mengenai hasil tes, maka terlebih dahulu perlu dibahas mengenai alat tes yang digunakan. Validitas isi yang dimiliki tes ini dipandang cukup untuk dijadikan pertimbangan dalam menggunakannya sebagai alat untuk memperoleh umpan balik efektifitas kegiatan pembelajaran. Skor tes awal dan tes akhir pembelajaran dianalisis dengan uji $\boldsymbol{t}$ dua sampel berhubungan. Hasilnya adalah sebagai berikut: (1) skor rata-rata tes awal 48,03 sedangkan skor rata-rata tes akhir 65,15. Harga $\boldsymbol{t}$ hitung adalah
8,10. Harga $\boldsymbol{t}$ tersebut menunjukkan bahwa terdapat perbedaan yang sangat signifikan antara skor tes awal dan tes akhir mahasiswa, setelah dikonsultasikan dengan nilai $\boldsymbol{t}$ tabel, yaitu 2,04. (2) dengan demikian dapat disimpulkan bahwa pembelajaran dengan menggunakan program multimedia yang dikembangkan ini efektif dalam rangka peningkatan pencapaian kompetensi mahasiswa.

\section{Simpulan dan Saran Simpulan}

Berdasarkan hasil penelitian program multimedia pembelajaran tipografi menunjukkan bahwa: pertama, data penelitian menunjukkan bahwa sebagian besar komponen program multimedia ini dinilai layak untuk digunakan, baik sebagai sumber maupun media pembelajaran. Kedua, keefektifan program ditunjukkan oleh skor yang diperoleh menunjukkan adanya peningkatan yang berarti pada skor tes akhir mahasiswa, setelah dibandingkan dengan skor tes awal. Berdasarkan simpulan di atas, maka hasil penelitian pengembangan program multimedia interaktif untuk pembelajaran tipografi ini dinilai efektif dan layak digunakan, baik untuk belajar mandiri, maupun pembelajaran di kelas.

\section{Saran}

Pertama, bagi dosen mata kuliah Disain Komunikasi Visual, hendaknya mencermati program pembelajaran tipografi ini untuk dijadikan bahan 
pertimbangan pada segmen mana yang dapat dijadikan sebagai media pembelajaran.Kedua, perlu peningkatan kemampuan dosen dalam mengenal dan menggunakan media pembelajaran, khususnya media yang berbasis komputer. Ketiga, perlu adanya penelitian lanjutan untuk mengetahui kekuatan dan kelemahan yang ada pada program ini dengan jumlah subyek yang lebih besar dan waktu yang digunakan sesuai dengan program pembelajaran. Keempat, bentuk evaluasi untuk soal latihan perlu divariasikan, tidak hanya dalam bentuk multiple-choice tetapi juga bentuk-bentuk soal yang lain. Kelima, bagi mahasiswa, hendaknya mempelajari program pembelajaran ini secara mandiri sebelum mengikuti pembahasan di ruang kelas.

\section{Pustaka Acuan}

Alessi, S.M. and Trollip, Stanley R. 1991. Computer Based Instruction Method and Development. Englewood Cliffs, NJ: Prentice-Hall, Inc.

Borg, Walter R. and Gall, Meredith D. 1973. Educational Research: An Introduction. New York: David McKay Company, Inc.

Folsom, Rose. 1990. The Calligraphers' Dictionary. London: Thames and Hudson Ltd.

Hannafin, Michael J. and Peck, Kyle L. 1988. The Design, Development, and Evaluation of Instructional Software. New York: Macmillan Publishing Company

http//www.pustekkom.go.id/multimedia+pembelajaran \& hal=id.

Kusrianto, Adi. 2004. Tipografi Komputer untuk Desainer Grafis. Yogyakarta: Andi

Nakanishi, Akira. 1988. Writing Systems of the World: Alphabets, Syllabaries, Pictograms. Tokyo: Charles E. Tuttle Company

Pannen, Paulina, Mustafa, Dina dan Sekarwinahyu. 2001. Konstruktivisme dalam Pembelajaran. Jakarta: Universitas Terbuka

Phillips, Rob. 1997. The Developer's Handbook to Interactive Multimedia:

A Practical Guide for Educational Applications. London: Kogan Page.

Reigeluth, Charles M. (Ed.) 1983. Instructional-Design Theories and Models: An Overview of their Current Status. New Jersey: Lawrence Erlbaum Associates, Inc., Publisher

http://www.pustekkom.go.id/multimedia.htm

Sadiman, Arief S. 1996. Media Pendidikan. Jakarta: CV. Rajawali-Pustekkom Depdikbud

Schwier, Richard A. and Misanchuk, Earl R. 1993. Interactive Multimedia Instruction. New Jersey: Educational Technology Publications, Inc.

Sirojuddin, AR. Seni Kaligrafi Islam. 2000. Bandung: Rosdakarya, Edisi Kedua

http://id.wikipedia.org/wiki/Tipografi, 22 Juli 2007 